(2) Open Access Full Text Article

\title{
Abortive lytic Epstein-Barr virus replication in tonsil-B lymphocytes in infectious mononucleosis and a subset of the chronic fatigue syndrome
}

This article was published in the following Dove Press journal:

Virus Adaptation and Treatment

7 November 2012

Number of times this article has been viewed

\author{
A Martin Lerner' \\ Safedin Beqaj ${ }^{2}$ \\ 'Department of Medicine, Oakland \\ University William Beaumont School \\ of Medicine, Rochester, MI, USA; \\ ${ }^{2}$ Pathology Inc, Torrance, CA, USA
}

Abstract: A systematic 2001-2007 review of 142 chronic fatigue syndrome (CFS) patients identified 106 CFS patients with elevated serum IgG antibodies to the herpesviruses EpsteinBarr virus (EBV), cytomegalovirus, or human herpesvirus (HHV) 6 in single or multiple infections, with no other co-infections detected. We named these 106 patients group-A CFS Eighty-six of these 106 group-A CFS patients (81\%) had elevated EBV early antibody, early antigen (diffuse), serum titers. A small group of six patients in the group-A EBV subset of CFS, additionally, had repetitive elevated-serum titers of antibody to the early lytic replicationencoded proteins, EBV dUTPase, and EBV DNA polymerase. The presence of these serum antibodies to EBV dUTPase and EBV DNA polymerase indicated EBV abortive lytic replication in these 6 CFS patients. None of 20 random control people (age- and sex-matched, with blood drawn at a commercial laboratory) had elevated serum titers of antibody to EBV dUTPase or EBV DNA polymerase $(P<0.01)$. This finding needs verification in a larger group of EBV CFS subset patients, but if corroborated, it may represent a molecular marker for diagnosing the EBV subset of CFS. We review evidence that EBV abortive lytic replication with unassembled viral proteins in the blood may be the same in infectious mononucleosis (IM) and a subset of CFS. EBV-abortive lytic replication in tonsil plasma cells is dominant in IM. No complete lytic virion is in the blood of IM or CFS patients. Complications of CFS and IM include cardiomyopathy and encephalopathy. Circulating abortive lytic-encoded EBV proteins (eg, EBV dUTPase, EBV DNA polymerase, and others) may be common to IM and CFS. The intensity and duration of the circulating EBV-encoded proteins might differentiate the IM and EBV subsets of CFS. Abortive lytic replication may be a pathogenic mechanism for EBV disease. EBV (HHV4) is a gamma herpesvirus composed of dsDNA about $170 \mathrm{~Kb}$ in length. For this discussion, there are early genes (including expressions of encoded proteins EBV dUTPase, DNA polymerase, and nuclear proteins) and late genes (including expressions of capsid and membrane proteins). Abortive infection infers incomplete virion expressions of either early or late proteins, but the virion is incomplete. The lytic virus infers a complete virion. The pathologic consequences of EBV abortive replication are currently being investigated by authors.

Keywords: Epstein-Barr virus, chronic fatigue syndrome, subset chronic fatigue syndrome, abortive lytic replication

\section{Background}

Chronic fatigue syndrome (CFS) is an orphan and a mystery. ${ }^{1-8}$ CFS patients and CFS physician-scientists are sometimes isolated by patients' families, friends, and other physicians who consider CFS a psychiatric condition. We have pursued pathologic physiology ${ }^{9-12}$ and reported tachycardias at rest, ${ }^{4}$ abnormal oscillating T-wave
Correspondence: A Martin Lerne 32804 Pierce Road, Beverly Hills, MI, 48025, USA

Tel + I 2485409866

Fax + I 2485400139

Email amartinlerner@yahoo.com 
electrical repolarizations with flat abnormal and ischemiclike T-waves, and, ultimately, cardiac dilatation with an associated, diminished left-ventricular ejection fraction. We found there to be primary cardiomyopathy at cardiac biopsy. ${ }^{5,6}$ In three peer-reviewed publications, including a placebo-controlled trial and a recent systematic review, we report longlasting clinical improvement with valacyclovir in Epstein-Barr virus (EBV) subset of CFS patients. ${ }^{1,12-14}$ Kogelnik et al have reported similar therapeutic results in human herpesvirus (HHV) 6/EBV subset group-A CFS with valganciclovir, ${ }^{8}$ and Jason et al estimate there are 800,000 CFS patients in the USA. ${ }^{15,16}$ CFS remains a conundrum.

EBV is a virtually universal human infection that is a primary infection in the tonsils with two target cells: epithelial cells and naïve B-lymphocytes. EBV is also a tumor-associated virus expressing latent EBV replication in Hodgkin's disease, nasopharyngeal carcinoma, Burkitt lymphoma, and gastric carcinoma. ${ }^{17-23} \mathrm{EBV}$ infection in the tonsillar ring of Waldeyer is associated with a soft exudate in infectious mononucleosis (IM), ${ }^{24}$ and there is an unrecognized pathognomonic, hard white exudate in some patients with the EBV subset of CFS (Lerner, unpublished data, 2002). Remarkably, even in acute IM, there is no complete virion infectious virus in the blood. ${ }^{3}$ Remarkably, too, a low level of EBV lytic replication continues in B-lymphocytes, in the tonsils, which have differentiated into plasma cells during the entire lifetime of every individual. ${ }^{25,26}$ After primary EBV infection in the tonsils, naïve B-lymphocytes in the tonsil differentiate into activated blasts and express the growth transcription programs EBNA 1, 2, 3A, 3C, LP, LMP1, and LMP2. These activated EBV-infected B-lymphocytes migrate to an adjacent oligoclonal germinal center, where they differentiate into memory B-cells ${ }^{27-29}$ (Figure 1). Within memory B-cells, EBV is a closed, nonreplicating intranuclear episome expressing only EBVNA1 and selected viral RNAs, which, when present, in turn allow the memory B-cell to divide and therefore expand its population while still in the periphery. According to Miyashita et al, ${ }^{27}$ memory B-cells safely leave the tonsil to enter the peripheral circulation expressing no detectable EBV complete virion. Memory B-cells in the circulation are safe from EBV cytolytic T-lymphocytes, which recognize mainly structural EBV-encoded proteins. ${ }^{30-33}$ EBV episomecarrying memory B-cells are long-lived and permanent residents in the periphery. Thorley-Lawson ${ }^{33}$ further posits that EBV-memory B-cells intermittently reenter the tonsils. In the tonsils, again, these EBV memory B-cells differentiate into plasma cells and replicate, again encoding EBV lytic proteins. These EBV lytic replicating plasma cells now may die by apoptosis, freeing complete virions into the saliva (Figure 1). ${ }^{30-36}$

EBV major envelope glycoprotein gp/350/220 binds to naïve B-lymphocyte membrane protein $\mathrm{C} 3 \mathrm{~d}$ complement receptor 2 (CR2/CD21) to infect virtually the entire human population. ${ }^{24,37,38}$ An elevated serum $\operatorname{IgG}$ antibody to the structural protein EBV viral capsid antigen (VCA) with a concomitant negative IgM VCA EBV serum antibody records past infection. ${ }^{39}$ Nevertheless, healthy people intermittently shed EBV infectious virus in their saliva. ${ }^{30,31}$

Quantitative studies of EBV replication during IM indicate lytic replication in the tonsils is in the minority, and abortive lytic replication is dominant. ${ }^{25,31,32}$ During acute IM, immune/inflammatory responses of both cell-mediated and humoral systems target multiple antigens, including latent and lytic-encoded proteins. Encoded proteins EBNA 1, 2, 3A, 3B, 3C, LMP1, and LMP2, and the early lytic cycle antigens, including the encoded genes BZLF1 (Zta), BRLF1 (Rta), and early antigen diffuse component (EA[D]) BMLF1, elicit responses. In IM, MHC cytolytic T-cell antigenic responses promptly free the periphery of lytic virus. ${ }^{30,31}$ Some healthy EBV immune carriers may have low titers of circulating serum antibody to EBV early antigen (diffuse) (EA[D]), which express early EBV epitopes 86-100 and 268-277..$^{18,26,35,37}$

\section{Recent findings Diagnostic panel and group-A and $-B$ subsets}

In order to define a laboratory-based EBV subset of CFS, we name CFS patients with elevated serum EBV EA(D) BMRF1 serum titers of antibody EBV subset group A. ${ }^{1}$ Other clinically identical group-A CFS patients have elevated serum IgG antibody titers to beta herpesviruses, for example, cytomegalovirus (CMV) or HHV6 in single or multiple infections, but no other co-infections. ${ }^{1}$ We describe a laboratory-based diagnostic panel, which assures a CFS homogenous group of patients. Previous CFS studies have been limited or based upon symptoms only. ${ }^{40-52}$ In our CFS systematic review, ${ }^{1}$ we found 36 additional so-called CFS patients who had serologic evidence of herpesviruses infection (EBV, CMV, HHV6) and one or more co-infections. Co-infections were tick-borne Borrelia burgdorferi, Babesia microti, Anaplasma (Ehrlichia) phagocytophilum, Mycoplasma pneumoniae, Chlamydia pneumoniae, or infection associated with rheumatic fever. From this systematic review, 


\section{B-lymphocyte EBV abortive lytic replication in a subset of CFS}

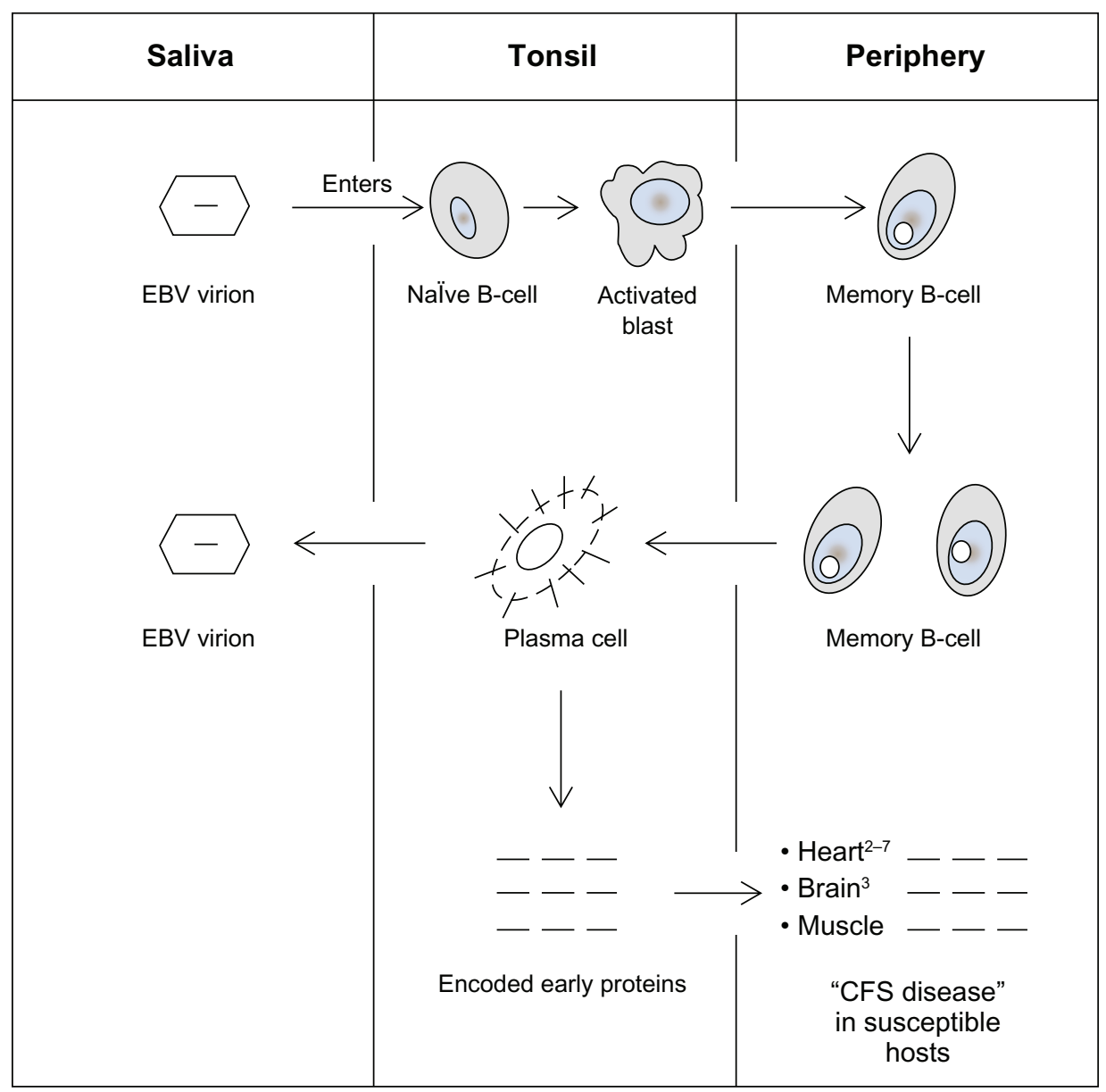

Figure I B-lymphocyte EBV abortive lytic replication in a subset of CFS.

Notes: Complete EBV virion is transferred by saliva (kisses) from an asymptomatic EBV carrier to primarily infect epithelial cells in the tonsils of the recipient, where lytic replication (complete virions) occurs. In turn, naïve B-lymphocytes of the recipient are infected. These B-lymphocytes differentiate into activated blasts in the tonsils. The activated blast B-lymphocytes then enter the periphery and become memory-B cells containing intranuclear EBV latent virus. ${ }^{28,29}$ Ultimately, the memory-B cells reenter the tonsils where again some of these memory B-cells differentiate into plasma cells. Again in the tonsils, plasma cell apoptosis with modest lytic replication, but marked abortive lytic replication ensues, producing the encoded proteins EBV DNA polymerase and EBV dUTPase, among others. These encoded proteins in CFS (and IM) enter the periphery, "producing" disease (myocarditis, encephalopathy, myositis, hepatitis, etc, in IM). ${ }^{4}$

Copyright @ 2004, American Society for Microbiology. Adapted with permission from: Hochberg D, Souza T, Catalina M, Sullivan JL, Luzuriaga K, Thorley-Lawson DA. Acute infection with Epstein-Barr virus targets and overwhelms the peripheral memory B-cell compartment with resting, latently infected cells. J Virol. 2004;78(I0):5I94-5204.25 Abbreviations: CFS, chronic fatigue syndrome; EBV, Epstein-Barr virus; IM, infectious mononucleosis.

we named the 36 additional CFS patients with co-infections group-B CFS. ${ }^{1}$

\section{Long-term CFS group and subset- directed EBV pharmacokinetic antiviral treatment}

Accepted canonical science interprets an absence of EBV VCA IgM antibody and the absence of EBV DNA-emia as signifying no active infection. ${ }^{39}$ The in vitro and animal model studies of Glaser et al ${ }^{53,54}$ suggest abortive lytic replication may be critical to IM and CFS; short-term acyclovir therapy has been unsuccessful. ${ }^{52}$ This CFS diagnostic panel (used here) was not available in earlier studies. ${ }^{1,40-52}$ The group-A CFS subset includes patients with EBV, CMV, and HHV6 infection, but with no other detected co-infections. Group-B CFS patients include EBV, CMV, and HHV6 infections with co-infections. EBV subset group-A CFS patients were treated with valacyclovir, and with valganciclovir only if elevated serum IgG antibody to CMV or HHV6 were also present. Valacyclovir (14.3 $\mathrm{mg} / \mathrm{kg}$ every [q] 6 hours) with valganciclovir (two, $450 \mathrm{mg}$ q 24 hours) was given for up to 12 months. (Valganciclovir was given q 12 hours as needed. ${ }^{1}$ ) Of the 106 group-A patients, 79 recovered to live normal lives (74.5\%, $P<0.0001) .{ }^{1}$ There was no EBV VCA IgM serum 
antibody in $90 \%$ of cases and no free EBV DNA-emia in the EBV subset of CFS. The EBV genome is latent in memory B-cells in the periphery and no lytic virus is in the blood. ${ }^{33}$ This dosage of valacyclovir and the duration of valacyclovir therapy distinguish our valacyclovir use from earlier trials of acyclovir by others, which failed to reverse the course of CFS. Valacyclovir is the prodrug of acyclovir. Acyclovir binds to EBV DNA, leading to irreversible viral inactivation and interruption of lytic replication at the level of EBV DNA polymerase. ${ }^{12}$ EBV latent replication is not interrupted. ${ }^{39}$ Valacyclovir levels in serum at this dosage ( $14.3 \mathrm{mg} / \mathrm{kg}$ q 6 hours $)$ reach anti-EBV inhibitory concentrations of $22 \mu \mathrm{m}\left(\mathrm{IC}_{50} \mathrm{EBV}, 4.4-13.3 \mu \mathrm{m}\right) .{ }^{13}$ To our knowledge, these results have not been previously reported. Clinical improvement began only after sixth months of valacyclovir treatment, and continued through 12 months. Accepted canonical science, however, interprets the absence of EBV VCA IgM antibody, and the absence of EBV DNA-emia, as not being EBV lytic replication. ${ }^{39,55}$

\section{Latest findings}

Lerner et $\mathrm{al}^{2}$ report on 6 of $19(32 \%)$ randomly selected people with low-titer elevated-serum antibody to the nonstructural encoded proteins EBV EA(D), BMRF1. ${ }^{2}$ In contrast, 86 of 106 (81\%) CFS patients in the 2001-2007 systematic review had elevated serum titers of antibody to the encoded EBV EA(D) proteins. ${ }^{1}$ At the 10th IACFS Conference for Physicians and Healthcare Professionals Translating Evidence into Practice (Ottawa, Canada, September 22-25, 2011), Lerner et $\mathrm{al}^{2}$ presented six group-A EBV subset of CFS patients who had elevated serum antibody to the encoded proteins EBV EA (D) and elevated serum-neutralizing antibody to the encoded proteins EBV DNA polymerase and EBV dUTPase. ${ }^{2}$ Elevated serum antibody to EBV DNA polymerase and EBV dUTPase persisted for at least 400 days. None of 20 controls had elevated serum antibody to the encoded proteins EBV DNA polymerase or EBV dUTPase $(P<0.01)$. These group-A EBV subsets of CFS patients had mean serum-neutralizing titers of antibody to EBV DNA polymerase of $60 \mathrm{u} / \mathrm{mL}$, compared to the mean $17 \mathrm{u} / \mathrm{mL}(P<0.01)$ of control titers. The six EBV group-A CFS patients demonstrates "EBV abortive lytic replication." 2

Miller et al, ${ }^{56}$ Jones et al, ${ }^{57}$ Liu et al, ${ }^{58}$ and Natelson et al ${ }^{59}$ have all reported elevated serum antibody values for both EBV DNA polymerase and EBV dUTPase in several CFS patients, but many CFS patients did not have these findings in each of the earlier studies. The classification of CFS patients to the group-A EBV subset of CFS made possible the recognition of this uniform group of CFS patients. This uniformity was achieved because of the diagnostic panel we reported, and its subsequent recognition of the group-A EBV subset. ${ }^{1}$

It is possible that elevated serum antibody to EBV dUTPase and EBV DNA polymerase separates EBV CFS subset patients from healthy immune carriers (Table 1). ${ }^{2}$ In vitro, encoded dUTPase ${ }^{53}$ and EBV-encoded Zta induce cellular dysregulation and apoptosis. ${ }^{60}$ Unassembled EBVencoded early proteins, including among others, EBV DNA polymerase and EBV dUTPase, may enter the periphery in both the IM and EBV subsets of CFS. We postulate that these circulating EBV-encoded abortive lytic proteins attach to cellular membranes and enter multiple organs, including the heart (cardiomyopathy), ${ }^{6,24}$ muscle (myositis), brain, and meninges (encephalopathy), ${ }^{8}$ and subsequently incite an explosive inflammatory response-producing disease. ${ }^{61}$ Symptoms and pathologic findings in the IM and EBV subsets of CFS may require the same circulating EBV-encoded proteins. Our recent findings of the prolonged presence of elevated serum antibodies to the encoded proteins EBV dUTPase and EBV DNA polymerase in the EBV subset of CFS, are consistent with this paradigm. This unifying concept for the IM and EBV subsets of CFS requires confirmation with a larger group of CFS patients and with appropriate controls. There is no in vitro model for EBV lytic replication, but the murine gammaherpesvirus 68 establishes a latent infection in mouse B-lymphocytes similar to that of EBV. ${ }^{62,63}$ We are aware that we offer a previously unrecognized herpesvirus pathogenesis for CFS and IM. The presence of unassembled circulating EBV early proteins such as the enzymes EBV DNA polymerase and EBV dUTPase may facilitate a sciencebased CFS diagnosis, and provide proof for the need for long-term antiviral therapy (Table 1).

Table I Paradigm: EBV replication in healthy immune people, and the EBV subset of CFS patients

\begin{tabular}{|c|c|c|}
\hline EBV & $\begin{array}{l}\text { Healthy EBV } \\
\text { immune people }\end{array}$ & $\begin{array}{l}\text { CFS EBV } \\
\text { subset patients }\end{array}$ \\
\hline Virions (saliva) & + & + \\
\hline Memory $\beta$-cell (periphery) & + & + \\
\hline VCA, IgM (serum) ${ }^{a}$ & - & $--^{a}$ \\
\hline VCA, IgG (serum) & + & + \\
\hline $\mathrm{EA}(\mathrm{D})(\text { serum })^{\mathrm{b}}$ & $-^{\mathrm{b}}$ & + \\
\hline $\begin{array}{l}\text { Antibody to DNA } \\
\text { polymerase (serum) }\end{array}$ & - & + \\
\hline Antibody to dUTPase (serum) & - & + \\
\hline
\end{tabular}

Notes: aEBV VCA IgM serum antibody may be present in 10\%-15\% of CFS patients. ${ }^{b} E B V E A(D)$ serum antibody may be in approximately $30 \%$ of healthy immune people.

Abbreviations: CFS, chronic fatigue syndrome; EA(D), early antigen (diffuse); EBV, Epstein-Barr virus; VCA, viral capsid antigen. 


\section{Disclosure}

The authors report the following conflicts: A Martin Lerner and Safedin Beqaj have ownership of CFS LLC, which owns US patents for diagnosis and treatment of CFS and pending patents distinguishing groups $\mathrm{A}$ and $\mathrm{B} \mathrm{CFS}$ :

\section{Patent number Patent title}

6,894,056 Method for diagnosing and alleviating the symptoms of chronic fatigue syndrome

6,537,997 Method for diagnosing and alleviating the symptoms of chronic fatigue syndrome

6,399,622 Method for diagnosing and alleviating the symptoms of chronic fatigue syndrome

6,258,818 Method for diagnosing and alleviating the symptoms of chronic fatigue syndrome

5,872,123 Method for diagnosing and alleviating the symptoms of chronic fatigue syndrome

$5,464,020 \quad$ Diagnosing and treating subacute cardiac dysfunction

5,357,968 Diagnosing and treating subacute myocarditis

5,213,106 Diagnosing and treating chronic fatigue syndrome by electrocardiographic monitoring of T-waves

Pending Methods for diagnosis and treatment of chronic fatigue syndrome

Ohio State University and CFS LLC have submitted a patent, "EBV DNA polymerase and EBV dUTPase in the EBV subset of CFS." Additionally, CFS LLC owns Certificates of Registration issued under the seal of the Copyright Office for the following works: Functional Activity Appraisal Energy Index Score; Health Care Worker Assessment; Quantitative CFS Physical Activity Assessment; Grading Scale for Energy Index Questionnaire; CFS: Based Upon Functional Capacity; EIPS: Energy Index Point Score Chart; A Functional Capacity Measurement Tool for Chronic Fatigue Syndrome (CFS) Patients. Safedin Beqaj is employed by Pathology, Inc. There are no further patents, products in development, marketed products, or other conflicts of interest to declare.

\section{References}

1. Lerner AM, Beqaj SH, Fitzgerald JT, Gill K, Gill C, Edington J. Subset-directed antiviral treatment of 142 herpesvirus patients with chronic fatigue syndrome. Virus Adaptation and Treatment. 2010;2:47-57.

2. Lerner AM, Ariza ME, Williams M, et al. Antibody to Epstein-Barr Virus deoxyuridine triphosphate nucleotidohydrolase and deoxyribonucleotide polymerase in a chronic fatigue syndrome subset. PLoS One. 2012. In press.

3. Rickinson AB, Epstein MA, Crawford DH. Absence of infectious Epstein-Barr virus in blood in acute infectious mononucleosis. Nature. $1975 ; 258(5532): 236$.
4. Lerner AM, Lawrie C, Dworkin HS. Repetitively negative changing $\mathrm{T}$ waves at 24-h electrocardiographic monitors in patients with the chronic fatigue syndrome. Left ventricular dysfunction in a cohort. Chest. 1993;104(5):1417-1421.

5. Dworkin HJ, Lawrie C, Bohdiewicz P, Lerner AM. Abnormal left ventricular myocardial dynamics in eleven patients with chronic fatigue syndrome. Clin Nucl Med. 1994;19(8):675-677.

6. Lerner AM, Zervos M, Dworkin HJ, et al. New Cardiomyopathy: pilot study of intravenous ganciclovir in a subset of the chronic fatigue syndrome. Infect Dis Clin Pract (Baltim Md). 1997;6(2):110-117.

7. Lerner AM, Dworkin HJ, Sayyed T, et al. Prevalence of abnormal cardiac wall motion in the cardiomyopathy associated with incomplete multiplication of Epstein-barr Virus and/or cytomegalovirus in patients with chronic fatigue syndrome. In Vivo. 2004;18(4):417-424.

8. Kogelnik AM, Loomis K, Hoegh-Petersen M, Rosso F, Hischier C, Montoya JG. Use of valganciclovir in patients with elevated antibody titers against Human Herpesvirus-6 (HHV-6) and Epstein-Barr virus (EBV) who were experiencing central nervous system dysfunction including long-standing fatigue. J Clin Virol. 2006;37 Suppl 1: S33-S38.

9. Fukuda K, Straus SE, Hickie I, Sharpe MC, Dobbins JG, Komaroff A. The chronic fatigue syndrome: a comprehensive approach to its definition and study. International Chronic Fatigue Syndrome Study Group. Ann Intern Med. 1994;121(12):953-959.

10. Carruthers B, Jain A, DeMeirleir K, et al. Myalgic encephalomyelitis/ chronic fatigue syndrome; clinical working case definition, diagnostic and treatment protocols. J Chronic Fatigue Syndr. 2003;11:7-115.

11. Stent GS. Prematurity and uniqueness in scientific discovery. Scientific American. 1972;227(6):84-93.

12. Lerner AM, Beqaj SH, Gill K, Edington J, Fitzgerald JT, Deeter RG. An update on the management of glandular fever (infectious mononucleosis) and its sequelae caused by Epstein-Barr virus (HHV-4): new and emerging treatment strategies. Virus Adaptation and Treatment. 2010;2:135-145.

13. Lerner AM, Beqaj SH, Deeter RG, et al. A six-month trial of valacyclovir in the Epstein-Barr virus subset of chronic fatigue syndrome: improvement in left ventricular function. Drugs Today (Barc). 2002; 38(8):549-561.

14. Lerner AM, Beqaj SH, Deeter RG, Fitzgerald JT. Valacyclovir treatment in Epstein-Barr virus subset chronic fatigue syndrome: thirty-six months follow-up. In Vivo. 2007;21(5):707-713.

15. Jason LA, Richman JA, Rademaker AW, et al. A community-based study of chronic fatigue syndrome. Arch Inter Med. 1999;159(18): 2129-2137.

16. Jason LA, Benton MC, Valentine L, Johnson A, Torres-Harding S. The economic impact of ME/CFS: individual and societal costs. Dyn Med. 2008;7:6.

17. Kieff E, Johannsen E, Calderwood M. Latent Epstein-Barr virus infections. In: Robertson E, editor. Epstein-Barr Virus, Latency and Transformation. Norfolk, UK: Caister Academic Press; 2010:1-24.

18. Hochberg D, Middeldorp JM, Catalina M, Sullivan JL, Luzuriaga K, Thorley-Lawson DA. Demonstration of the Burkitt's lymphoma Epstein-Barr virus phenotype in dividing latently infected memory cells in vivo. Proc Natl Acad Sci U S A. 2004;101(1):239-244.

19. Thorley-Lawson DA, Gross A. Persistence of the Epstein-Barr virus and the origins of associated lymphomas. New Engl J Med. 2004;350(13): 1328-1337.

20. Kaye KM, Izumi KM, Kieff E. Epstein-Barr virus latent membrane protein 1 is essential for B-lymphocyte growth transformation. Proc Natl Acad Sci U S A. 1993;90(19):9150-9154.

21. Clemens MJ. Epstein-Barr virus: inhibition of apoptosis as a mechanism of cell transformation. Int J Biochem Cell Biol. 2006;38(2):164-169.

22. Greenspan JS, Greenspan D, Lennette ET, et al. Replication of EpsteinBarr virus within the epithelial cells of oral "hairy" leukoplakia, an AIDS-associated lesion. New Engl J Med. 1985;313(25):1564-1571.

23. Shibata D, Weiss LM. Epstein-Barr virus-associated gastric adenocarcinoma. Am J Pathol. 1992;140(4):769-774. 
24. Cohen J. Epstein-Barr virus infections including infectious mononucleosis. In: Braunwald E, Fauci A, Isselbacher K, et al, editors. Harrison's Principles of Internal Medicine. Boston: McGraw-Hill; 1999.

25. Hochberg D, Souza T, Catalina M, Sullivan JL, Luzuriaga K, ThorleyLawson DA. Acute infection with Epstein-Barr virus targets and overwhelms the peripheral memory B-cell compartment with resting, latently infected cells. J Virol. 2004;78(10):5194-5204.

26. Anagnostopoulos I, Hummel M, Kreschel C, Stein H. Morphology, immunophenotype, and distribution of latently and/or productively Epstein-Barr virus-infected cells in acute infectious mononucleosis: implications for the interindividual infection route of Epstein-Barr virus. Blood. 1995;85(3):744-750.

27. Miyashita EM, Yang B, Babcock GJ, Thorley-Lawson DA. Identification of the site of Epstein-Barr virus persistence in vivo as a resting B cell. J Virol. 1997;71(7):4882-4891.

28. Liu YJ, Arpin C. Germinal center development. Immunol Rev. 1997;156: $111-126$.

29. Tough DF, Sprent J. Lifespan of lymphocytes. Immunol Res. 1995;14(1): $1-12$.

30. Babcock GJ, Decker LL, Freeman RB, Thorley-Lawson DA. Epstein-Barr virus-infected resting memory B cells, not proliferating lymphoblasts, accumulate in the peripheral blood of immunosuppressed patients. J Exp Med. 1999;190(4):567-576.

31. Yao QY, Ogan P, Rowe M, Wood M, Rickinson AB. Epstein-Barr virus-infected $B$ cells persist in the circulation of acyclovir-treated virus carriers. Int J Cancer Suppl. 1989;43(1):67-71.

32. Babcock GJ, Decker LL, Volk M, Thorley-Lawson DA. EBV persistence in memory B cells in vivo. Immunity. 1998;9(3):395-404.

33. Thorley-Lawson DA. Epstein-Barr virus: exploiting the immune system. Nat Rev Immunol. 2001;1(1):75-82.

34. Tanner J, Weis J, Fearon D, Whang Y, Kieff E. Epstein-Barr virus gp350/220 binding to the $\mathrm{B}$ lymphocyte $\mathrm{C} 3 \mathrm{~d}$ receptor mediates adsorption, capping, and endocytosis. Cell. 1987;50(2):203-213.

35. Hadinoto V, Shapiro M, Sun CC, Thorley-Lawson DA. The dynamics of EBV shedding implicate a central role for epithelial cells in amplifying viral output. PLoS Pathog. 2009;5(7):e1000496.

36. Sixbey JW, Nedrud JG, Raab-Traub N, Hanes RA, Pagano JS. Epstein-Barr virus replication in oropharyngeal epithelial cells. New Engl J Med. 1984;310(19):1225-1230.

37. Laichalk LL, Thorley-Lawson DA. Terminal differentiation into plasma cells initiates the replicative cycle of Epstein-Barr virus in vivo. JVirol. 2005;79(2):1296-1307.

38. Perry M, Whyte A. Immunology of the tonsils. Immunol Today. 1998; 19(9):414-421.

39. Lerner AM, Beqaj SH. A paradigm linking herpesvirus immediateearly gene expression apoptosis and myalgic encephalomyelitis chronic fatigue syndrome. Virus Adaptation and Treatment. 2011;3:19-24.

40. Jones JF, Ray CG, Minnich LL, Hicks MJ, Kibler R, Lucas DO. Evidence for active Epstein-Barr virus infection in patients with persistent, unexplained illnesses: elevated anti-early antigen antibodies. Ann Intern Med. 1985;102(1):1-7.

41. Patnaik M, Komaroff AL, Conley E, Ojo-Amaize EA, Peter JB. Prevalence of $\operatorname{IgM}$ antibodies to human herpesvirus 6 early antigen (p41/38) in patients with chronic fatigue syndrome. J Infect Dis. 1995; 172(5):1364-1367.

42. Sairenji T, Yamanishi K, Tachibana Y, Bertoni G, Kurata T. Antibody responses to Epstein-Barr virus, human herpesvirus 6 and human herpesvirus 7 in patients with chronic fatigue syndrome. Intervirology. 1995;38(5):269-273.

43. Straus SE, Tosato G, Armstrong G, et al. Persisting illness and fatigue in adults with evidence of Epstein-Barr virus infection. Ann Intern Med. 1985;102(1):7-16.
44. Tynell E, Aurelius E, Brandell A, et al. Acyclovir and prednisolone treatment of acute infectious mononucleosis: a multicenter, doubleblind, placebo-controlled study. J Infect Dis. 1996;174(2):324-331.

45. van der Horst C, Joncas J, Ahronheim G, et al. Lack of effect of peroral acyclovir for the treatment of acute infectious mononucleosis. J Infect Dis. 1991;164(4):788-792.

46. Buchwald D, Ashley RL, Pearlman T, Kith P, Komaroff AL. Viral serologies in patients with chronic fatigue and chronic fatigue syndrome. J Med Virol. 1996;50(1):25-30.

47. Buchwald D, Sullivan JL, Komaroff AL. Frequency of 'chronic active Epstein-Barr virus infection' in a general medical practice. JAMA. 1987;257(17):2303-2307

48. Di Luca D, Zorzenon M, Mirandola P, Colle R, Botta GA, Cassai E. Human herpesvirus 6 and human herpesvirus 7 in chronic fatigue syndrome. J Clin Microbiol. 1995;33(6):1660-1661.

49. Hellinger WC, Smith TF, Van Scoy RE, Spitzer PG, Forgacs P, Edson RS. Chronic fatigue syndrome and the diagnostic utility of antibody to Epstein-Barr virus early antigen. JAMA. 1988;260(7):971-973.

50. Hickie I, Davenport T, Wakefield D, et al. Post-infective and chronic fatigue syndromes precipitated by viral and non-viral pathogens: prospective cohort study. BMJ. 2006;333(7568):575.

51. Holmes GP, Kaplan JE, Stewart JA, Hunt B, Pinsky PF, Schonberger LB. A cluster of patients with a chronic mononucleosis-like syndrome. Is Epstein-Barr virus the cause? JAMA. 1987;257(17):2297-2302.

52. Straus SE, Dale JK, Tobi M, et al. Acyclovir treatment of the chronic fatigue syndrome. Lack of efficacy in a placebo-controlled trial. New Engl J Med. 1988;319(26):1692-1698.

53. Glaser R, Litsky ML, Padgett DA, et al. EBV-encoded dUTPase induces immune dysregulation: implications for the pathophysiology of EBVassociated disease. Virology. 2006;346(1):205-218.

54. Glaser R, Padgett DA, Litsky ML, et al. Stress-associated changes in the steady-state expression of latent Epstein-Barr virus: implications for chronic fatigue syndrome and cancer. Brain Behav Immun. 2005;19(2): 91-103.

55. Lerner AM, Beqaj SH, Deeter RG, Fitzgerald JT. IgM serum antibodies to Epstein-Barr virus are uniquely present in a subset of patients with the chronic fatigue syndrome. In Vivo. 2004;18(2):101-106.

56. Miller RL, Glaser R, Rapp F. Studies of an Epstein-Barr virus-induced DNA polymerase. Virology. 1977;76(2):494-502.

57. Jones JF, Williams M, Schooley RT, Robinson C, Glaser R. Antibodies to Epstein-Barr virus-specific DNase and DNA polymerase in the chronic fatigue syndrome. Arch Inter Med. 1988;148(9):1957-1960.

58. Liu MY, Chou WH, Nutter L, Hsu MM, Chen JY, Yang CS. Antibody against Epstein-Barr virus DNA polymerase activity in sera of patients with nasopharyngeal carcinoma. J Med Virol. 1989;28(2):101-105.

59. Natelson BH, Ye N, Moul DE, et al. High titers of anti-Epstein-Barr virus DNA polymerase are found in patients with severe fatiguing illness. J Med Virol. 1994;42(1):42-46.

60. Lin Z, Flemington EK. Regulation of EBV latency by viral lytic proteins. In: Robertson E, editor. Epstein-Barr Virus: Latency and Transformation. Norfolk, UK: Caister Academic Press; 2010:167-192.

61. Klimas NG, Koneru AO. Chronic fatigue syndrome: inflammation, immune function, and neuroendocrine interactions. Curr Rheumatol Rep. 2007;9(6):482-487.

62. Efstathiou S, Ho YM, Hall S, Styles CJ, Scott SD, Gompels UA. Murine herpesvirus 68 is genetically related to the gammaherpesviruses Epstein-Barr virus and herpesvirus saimiri. J Gen Virol. 1990;71(Pt 6): 1365-1372.

63. Sunil-Chandra NP, Efstathiou S, Nash AA. Murine gammaherpesvirus 68 establishes a latent infection in mouse B lymphocytes in vivo. J Gen Virol. 1992;73(Pt 12):3275-3279. 
Virus Adaptation and Treatment

\section{Publish your work in this journal}

Virus Adaptation and Treatment is an international, peer-reviewed open access journal focusing on the study of virology, viral adaptation and the development and use of antiviral drugs and vaccines to achieve improved outcomes in infection control and treatment. The journal welcomes original research, basic science, clinical \& epidemiological

studies, reviews \& evaluations, expert opinion and commentary, case reports and extended reports. The manuscript management system is completely online and includes a very quick and fair peer-review system, which is all easy to use. Visit http://www.dovepress.com/ testimonials.php to read real quotes from published authors.

Submit your manuscript here: http://www.dovepress.com/virus-adaptation-and-treatment-journa 